\title{
Workshop Penyusunan RPP Dalam Kurikulum Darurat Pada Masa Pandemi Covid-19
}

\author{
Muh Hasan Marwiji, Adi Rosadi, Eneng Yeni Mariah, Jimatul Arrobi \\ STAI Sukabumi \\ adyrosady27@gmail.com
}

\begin{abstract}
ABSTRAK
Keberhasilan pendidikan antara lain sangat didetetapkan oleh kedudukan guru dalam menyusun perencanaan pembelajaran. Salah satu proses perencanaan pembelajaran yang berhubungan langsung dengan proses pembelajaran yang hendak dijalankan guru diwujudkan dalam wujud Rencana Penerapan pembelajaran. Tujuan pengabdian kepada masyarakat yaitu untuk memberikan pengatahuan dan mampu membuat rencana pelaksanaan pembelajaran pada masa pandemi Bahan yang digunakan yaitu power point dan contoh RPP kurikulum Adapun metode yang dipakai yaitu metode ceramah, diskusi dan praktik serta pendampingan. Hasil pengabdian kepada masyarakat kegiatan pelatihan kegiatan pelatihan membantu guru proses pemahaman dan pembuatan penyusunan RPP pada masa kurikulum darurat. Peserta pelatihan begitu antusias mengikuti kegiatan workshop RPP dalam Kurikulum Darurat pada Masa Pandemi (COVID-19). Peserta begitu antusias mengikuti kegiatan. Kesimpulannya adalah bahwa kegiatan pengabdian kepada masyarakat workshop RPP dalam Kurikulum Darurat pada Masa Pandemi (COVID-19) dapat membantu guru dalam merencanakan proses pembelajaran.
\end{abstract}

Kata kunci : Workshop, Kurikulum, RPP

\begin{abstract}
The success of education, among others, is strongly determined by the position of teachers in preparing learning planning. One of the learning planning processes that is directly related to the learning process that the teacher wants to run is realized in the form of a learning implementation plan. The purpose of community service is to provide knowledge and be able to make a learning implementation plan during the pandemic Materials used are power points and examples of RPP curriculum As for the methods used are lecture methods, discussions and practices and mentoring. The results of community service training activities help teachers the process of understanding and making RPP preparation during the emergency curriculum. The trainees were enthusiastic about participating in rpp workshop in emergency curriculum during pandemic (COVID-19). Participants are so enthusiastic to participate in the activity. The conclusion is that community service activities rpp workshop in emergency curriculum during pandemic (COVID-19) can help teachers in planning the learning process.
\end{abstract}

Keywords : Workshop, Curriculum, RPP 


\section{PENDAHULUAN}

Keberhasilan proses pendidikan dipengaruhi oleh kondisi dan perencanaan proses pembelajaran. Guru perlu menyusun perencanaan sebelum proses pembelajaran yang bertujuan proses pendidikan lebih terarah dan juga proses evaluasi yang lebih akurat. Proses penyusunan rencana pelakasanan diwujdukan dengan guru harus menggunakan RPP.

Kegiatan proses pembelajaran tidak akan berjalan dengan baik tanpa adanya perencanaan yang baik dalam pembelajaran. Perencanaan pembelajaran merupakan bagian penting dalam pelaksanaan pendidikan di sekolah. Oleh karena itu, perencanaan memegang peranan penting dalam setiap kegiatan, termasuk dalam sebuah pembelajaran

Hal ini juga tertuang dalam kermendikbud No 22 Tahun 2016 bahwa

"Guru harus RPP secara lengkap serta sistematis supaya proses pembelajaran berlangsung secara interaktif, inspiratif, mengasyikkan, menantang, efektif, memotivasi siswa agar berpartisipasi aktif, dan memberiakan ruang yang lumayan untuk prakarsa, kreativitas, serta kemandirian yang disesuaikan dengan bakat, atensi, serta pertumbuhan raga dan psikologis siswa. (Mawardi, 2019)

Guru dituntut sanggup mempraktikkan metode proses pembelajaran yang cocok dengan muatan materi pembelajaran dan kepribadian siswanya. Tujuannya adalah untuk penggunaan metode dan teknik yang digunakan disesuaikan dengan tingkat perkembangan siswa.
Apalagi dalam kondisi covid-19 guru harus mampu menyesuaikan dengan kondisi yang ada. Kurikulum juga mengharuskan dikondisikan dengan situasi yang ada yaitu penggunaan kurikulum darurat.

Kurikulum yang disusun serta dilaksanakan oleh Sekolah di masa darurat ini berkaitan dengan perencanaan proses pembelajaran, aktivitas proses pembelajaran serta evaluasi hasil belajar yang disesuaikan dengan keadaan darurat serta dialami oleh tiap satuan sekolah. (Jusuf, 2020)

Kurikulum darurat pada dasarnya memiliki fleksibilitas. Karenna satuan pendidikan dapat mendesai bagaimana struktur kurikulum yang ada, proses pembelajaran dan juga materi pembelajaran. Selain itu juga, penggunaan media disesuaikan dengan kondisi sekolah yang beorientasi pada proses pengemabangan pengtahua, keterampilan kepribadian dan juga peningkatan keahlian yang tidak lepas dari. (Munajim et al., 2020)

Fenomena yang ada dilapangan bahwa masih ditemukannya guru kesulitan dalam pnenyusunan RPP khusunya dalam masa kurikulum darurat.

Terdapat tiga opsi yang dapat digunakan sekolah dalam pelaksanaan kurikulm darurat yaitu menggunakan kurikulum naisonal, kurikulum darurat yang sudah diterbitkan oleh kementrian atau kurikulum yang sudah disesuaikan dan disederhanakan oleh satuan pendidikan. mandiri oleh sekolah. (Jaka Bangkit Sanjaya, 2020) 
Guru menyadari bahwa RPP membuat perencanaan pelaksanaan merupakan pedoman dalam pelaksanaan pembelajaran pada masa pandemi. pembelajaran di dalam kelas. Rasa akan tanggungjawab dalam menciptakan proses pembelajaran yang baik, mendorong untuk mengadakan pendampingan dan pelatihan dalam menyusun RPP. Guru jula belajar dari pengalaman yang sudah mereka lalui dalam melakukan tugas keguruan. Rencana Penerapan Pendidikan merupakan pedoman guru dalam proses pembelajaran supaya lebih memberikan arah dalam melaksanakan pembelajaran. (Mawardi, 2019)

Komponen perencanaan mempengaruhi apa yang akan terjadi pada komponen interaksi. Selanjutnya apa yang terjadi pada komponen interaksi akan berpengaruh pada komponen evaluasi. Komponen evaluasi ini kemudian memberikan informasi mengenai hasil belajar yang telah dimiliki siswa. Dari informasi tersebut, guru dapat menemukan apakah kompetensi yang ditetapkan telah dikuasai atau belum. Di samping itu, guru dapat pula menentukan hal-hal yang harus diperbaiki, baik pada komponen interaksi maupun pada komponen perencanaan.

Pelaksanaan pembelajaran di masa pandemic covid 19 mengacu pada panduan pelaksanaan kurikulum darurat dan Permendikbud No 37 Tahun 2018. Kedua regulasi tersebut dilaksanakan dalam proses pembelajaran. (Nilasari \& Balai, 2020)

Tujuan dari dilakukannya pengabdian kepada masyarakat ini adalah untuk memberikan pengatahuan dan mampu

\section{BAHAN DAN METODE}

Kegiatan workshop Penyusunan RPP dalam Kurikulum Darurat pada Masa Pandemi (COVID-19) dilaksanakan pada tanggal 23 juli 2020 dengan jumlah peserta yaitu 40 orang. Metode yang digunakan yaitu ceramah, diskusi dan pendektan kajia teoritis.

Adapun jenis bahan yang digunakan yaitu file powerpoint dan rancangan kurikulum darrurat yang diterbitkan oleh kementrian Pendidikan dan kebudayaan. Pelaksanaan kegiatan dievaluasi dengan menggunakan kuesioner dan juga memberikan Pre-Test dan Post-Test. Adapun keriteria yang digunakan yaitu 1) Sangat Kurang 2) Kurang 3) Cukup, 4) Baik, dan 5) sangat Baik. Adapun pelaksanaan dilakukan melalui zoom meeting.

\section{HASIL}

Pelaksannan kegiatan pengabdian kepada masyarakat melalui kegiatan Workshop Penyusunan RPP dalam Kurikulum Darurat pada Masa Pandemi (COVID-19) dilaksanakan dengan tahap-tahap yaitu pembukaan, sambutan, pemaparan materi, diskusi dan tanyajawab. Yang kemudian dilakukan evaluasi dan penutup.

Pada tahap pembukaan semua peserta mengikuti dengan khidmat kegiatan yang selanjutnya dilaksanakan sambutan dari panitia yaitu yang menyampaikan bahwa pentingnya penyesuaian kurikulum dan 
penggunaan perencanaan pelaksanaan pembelajaran pada masa darurat.

Adapun dalam penyusunan RPP dalam Kurikulum Darurat pada Masa Pandemi (COVID-19) diperlukan beberapa komponen yang harus dikuasai yaitu mencangkup ketercapaian materi, program, dan kegiatan. Sebelum pelaksanaan kegiatan peserta dilakukan pretes dan dapat diketahui bahwa peserta belum sepenuhnya mengerti akan bagaimana RPP dalam Kurikulum Darurat pada Masa Pandemi (COVID-19).

Sedangkan setelah pelaksanaan angka pengetahuan peserta meningkat. Hal ini dapat dilihat dari ketercapaian materi didapatkan dari hasil survey tentang tanggapan terhadap materi dan pelayanan. Adapun hasil tanggapan terhadap pelayanan dan materi adalah baik atau di atas $80 \%$ merasa puas.

Selain hanya teoritis kegiatan workshop RPP dalam Kurikulum Darurat pada Masa Pandemi (COVID-19) juga diberikan materi praktik dimana peserta diberikan waktu untuk membuat RPP dalam massa Covid-19.

Pelaksanaan workshop RPP dalam Kurikulum Darurat pada Masa Pandemi (COVID-19) dibagi menjadi tiga yaitu pemaparan materi, praktik, dan tanya jawab. Peserta begitu antusias mengikuti kegiatan RPP dalam Kurikulum Darurat pada Masa Pandemi (COVID-19) hal ini dibuktikan dengan keaktifan peserta dalam pelaksanaan kegiatan.

Pelatihan pembuatan RPP Kurikulum darurat covid-19 ini berpedoman pada modul maupun kompetensi dasar esensial yang ditetapkan kemendikbud yang bertujuan agar tidak membebani siswa. Proses kegiatan ini diharapkan bisa membantu proses belajar dari rumah dengan mencakup penjelasan proses pembelajaran berbasis kegiatan untuk guru, orangtua, serta siswa.

Diakhir kegiatan peserta yang telah menyimak materi yang disampaikan oleh pemateri dalam workshop RPP Kurikulum Darurat pada Masa Pandemi (COVID-19) selanjutnya diberikan tugas untuk membuat contoh RPP kurikulum darurat.

\section{PEMBAHASAN}

Kurikulum merupakan bagian yang tidak dapat dipisahkan dalam proses pembelajaran. Kurikulum Darurat merupakan kurikulum yang simpel yang bisa mengkurangi beban mengajar sehingga guru bisa berfokus pada proses pembelajaran yang esensial serta konstektual.

Siswa diharapkan tidak terbebani tuntutan kurikulum sekolah yang wajib terpenuhi. Tidak hanya itu terdapatnya Kurikulum Darurat ini diharapkan dapat memudahkan proses pendampingan yang dilakukan orang tua/wali. Diharapkan pula kurikulum pendididkan ini bisa meningkatkan kesejahteraan psikososial guru, siswa, serta orang tua/ wali. (Jaka Bangkit Sanjaya, 2020)

Penelitian ini juga dilakukan oleh (Meirza Nanda Faradita, 2021) bahwa peserta pelatihan dapat mempraktikkan pembuatan RPP kurikulum darurat covid- 19 beserta evaluasinya agar dalam proses pembelajaran berjalan dengan optimal dan tidak membebani 
siswa dengan modul pembelajaran dikala kurikulum 2013.

RPP kurikulum darurat covid-19 ini mengurangi beberapa materi dari kurikulum 2013 agar dapat diajarkan kepada siswa di rumah. Siswa dapat belajar mandiri di rumah maupun didampingi orangtua agar pelaksanaan pembelajaran dapat berjalan dengan baik.

Kurikulum darurat pelaksanaannya bisa dilaksanakan dengan pengurangan kompetensi dasar untuk tiap mata pelajaran sehingga guru serta siswa bisa berfokus pada kompetensi esensial serta kompetensi prasyarat untk kelanjutan pendidikan di tingkatan berikutnya.

Kurikulum darurat covid 19 memberikan fleksibilitas untuk sekolah agar dapat memilah kurikulum yang cocok dengan kebutuhan pendidikan. Ini maksudnya sekolah bisa memakai kurikulum darurat dalam keadaan spesial semacam dikala pandemi covid 19 ini. Pelaksanaannya disesuaikan dengan keadaan sekolah dengan senantiasa mencermati protokol kesehatan seperti yang tertuang dalam SKB 4 menteri

Aktivitas penyesusunan RPP yang disesuaikan dengan KI/ KD kurikulum darurat covid 19, RPP terbuat simpel tetapi senantiasa mencermati isi/ poin guna pemenuhan dokumen akreditasi yang hendak tiba. Penentuan tata cara, fasilitas, serta metode evaluasi seluruhnya tertuang dalam RPP sehingga terlihat jelas. "Pembuatan RPP daring dalam kurikulum darurat covid 19 wajib senantiasa mencermati borang akretasi sehingga dokumen nantinya bisa dipakai dikala pelaksaan akreditas"(Hasanah et al., 2021)

Kegiatan pengabdian kepada masyarakat melalui pelatihan membantu guru dalam proses pemahaman dan pembuatan penyusunan RPP pada masa kurikulum darurat. Peserta pelatihan begitu antusias mengikuti kegiatan workshop RPP dalam Kurikulum Darurat pada Masa Pandemi (COVID-19)

Pentinya kurikulum dikarenakan Rencana Pelaksanaan Pembelajaran merupakan sebuah rencana yang menggambarkan akan adanya prosedur dan menajemen pembelajaran guna mencapai satu atau lebih kompetensi dasar yang telah dijabarkan dalam silabus.

RPP digunakan oleh setiap pengajar yang dijadikan sebagai pedoman umum untuk melaksanakan pembelajaran kepada peserta didiknya, karena di dalamnya berisi petunjuk secara rinci, pertemuan demi pertemuan, mengenai tujuan, ruang lingkup materi yang harus diajarkan, kegiatan belajar mengajar, media, dan evaluasi yang harus digunakan, paparnya.

Oleh kerena itu, adanya pelatihan ini membantu guru dalam memahami dan menyusun pentingnya Rencana Pelaksanaan pembelajaran sebelum dilaksanakan di dalam kelas. Guru harus selalu berupaya meningkatkan kualitas perencanaannya agar tujuan proses pembelajaran tercapai. 


\section{KESIMPULAN DAN SARAN}

Berdasarkan hasil kegiatan pengabdian kepada masyarakat dapat disimpulkan bahwa kegiatan pelatihan membantu guru proses pemahaman dan pembuatan penyusunan RPP pada masa kurikulum darurat. Peserta pelatihan begitu antusias mengikuti kegiatan workshop RPP dalam Kurikulum Darurat pada Masa Pandemi (COVID-19).

\section{UCAPAN TERIMA KASIH}

Ucapan terima kami sampaikan kepada Lembaga Pengabdian dan Penelitian kepada Masyarakat (LPPM) STAI Sukabumi yang telah memonitor kegiatan pengabdian kepada Masyarakat. dan juga kepada seluruh dewan guru yang telah berpartisipasi dalam kegiatan kegiatan pengabdian kepada Masyarakat.

\section{DAFTAR PUSTAKA}

Hasanah, E., Pendidikan, M., Pendidikan, F. I., \& Dahlan, U. A. (2021). Penerapan Kurikulum Darurat Pada Masa Covid-19 Di SMK Muhammadiyah Semin , Yogyakarta. Jurnal Ilmiah Mandala Education, 7(2), 9-18.

Jaka Bangkit Sanjaya, R. (2020). IMPLEMENTASI KURIKULUM DARURAT DI MASA PANDEMI COVID-19 DALAM UPAYA PEMENUHAN HAK PENDIDIKAN. Journal of Indonesian Law, 1, 161-174. https://doi.org/10.18326/jil.v1i2.161-174

Jusuf, R. (2020). Kurikulum Darurat Covid 19 di Kota Kotamobagu; Fenomena dan Realita Guru Madrasah. Jurnal Ilmiah Iqra, 2, 155-170.

Mawardi. (2019). Optimalisasi Kompetensi Guru Dalam Penyusunan Rencana Pelaksanaan Pembelajaran. Jurnal Ilmiah DIDAKTIKA, 20(1), 69-82.

Meirza Nanda Faradita, K. D. A. A. (2021). Pelatihan Pembuatan RPP Kurikulum Darurat Pada Masa Pandemi Covid-19.
JURNAL ALTIFANI, 1(3), 258-266. https://doi.org/10.25008/altifani.v1i3.16 6

Munajim, A., Barnawi, \& Fikriyah. (2020). Pengembangan Kurikulum Pembelajaran di Masa Darurat. Dwija Cendekia, 4(2), 285-291.

Nilasari, K. E., \& Balai. (2020). PEMBELAJARAN BAHASA INDONESIA DI MASA PANDEMI COVID 19. Lentera: Jurnal Diklat Keagamaan Padang, 5(1), 15-28. 